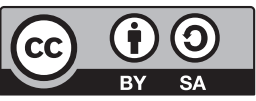

DOI 10.31261/IJREL.2019.5.2.04

\title{
Elżbieta Sanecka
}

Poland (ORCID: 0000-0003-3401-2782)

\section{Procrastination in Blended Learning The Role of General Self-efficacy, and Active and Passive Procrastination}

\begin{abstract}
Despite the growing empirical interest in academic procrastination in the distance learning, there are only limited studies on the determinants of this phenomenon in the blended learning programmes. The present study investigates the relationships between general self-efficacy, two types of procrastination (active and passive procrastination), and the behavioural tendency to postpone learning activities in a blended learning university course using Moodle platform. Results indicate that passive procrastination is strongly positively associated with procrastination in blended learning, while perceived self-efficacy and active procrastination are unrelated to the self-reported task delays during the blended learning course. In addition, the negative link between the reported number of previous completed blended-learning courses and procrastination in blended learning is observed. Practical and theoretical implications of these findings for a blended learning environment are discussed.
\end{abstract}

K e y w o r d s: procrastination, blended learning, self-efficacy, active procrastination, passive procrastination 


\section{Introduction}

The rapid growth of web-based technologies in the last years has radically changed learning environments, contributing to the increased popularity of blended learning systems in the work and educational settings (Graham, 2006). In general, such systems integrate traditional (synchronous) classroom face-to-face learning activities with (asynchronous) online learning experiences (Garrison \& Kanuka, 2004). The results of meta-analysis by Means et al. (2013) proved the effectiveness of blended learning in the education context. However, successful participation in a blended learning course requires the learner to possess self-regulation attributes, including perceived self-efficacy, which plays a key role in motivation to participate in distance learning programmes (Lynch \& Dembo, 2004). Thus, due to the selfdirected character of learning in the technology-mediated environments, many researchers explore academic procrastination in web-based education from the self-regulatory perspective (Cerezo et al., 2017; Shea \& Bidjerano, 2010).

In line with this approach, the present study aimed to investigate the relationships between general self-efficacy, active and passive procrastination, and selfreported procrastination in the blended learning course via Moodle platform among Polish students. Although previous findings show that academic procrastination is a cross-cultural phenomenon, it has been mainly explored in the individualistic countries (Ferrari, O’Callaghan, \& Newbegin, 2005; Klassen, Krawchuk, \& Rajani, 2008). Moreover, several past studies on procrastination in the academic sphere among Polish students concentrated only on the learning activities during traditional, face-to-face courses (e.g., Jaworska-Gruszczyńska, 2016; Markiewicz \& Dziewulska, 2018; Stępień \& Topolewska, 2014). Therefore, this study focused on investigating procrastination in blended learning on the sample from the Polish student population.

\section{Theoretical Background of the Research}

In general, procrastination is usually identified with a dispositional tendency to engage in a task delay, stemming from self-regulatory deficits (van Eerde, 2003; Steel, 2007). Although some research indicates its prevalence among adults from the general population, who often procrastinate chronically (Ferrari et al., 2005), to date most studies have concentrated on investigating procrastination among university students (Klingsieck, 2013b). Academic procrastination has been found as not only a common, but also costly and problematic phenomenon, negatively affecting students' achievements and performance at various levels of university 
education (van Eerde, 2003; Kim \& Seo, 2015). Moreover, its negative longterm consequences were also observed in reference to students' health and wellbeing (Sirois \& Pychyl, 2013). Given the problematic nature of the dysfunctional form of procrastination, according to Steel and Klingsieck (2016) the analysis of its antecedents is of particular significance for projecting the evidence-based interventions in academic settings. The current study alludes to this research framework by investigating potential individual differences determinants of academic procrastination in the online learning context, including general selfefficacy along with active and passive procrastination.

The tendency to voluntarily delay different activities needed to complete the scholastic tasks was noted during both traditional and online courses conducted by universities (see: Dunn, 2014; Gafni \& Geri, 2010). Additionally, the negative consequences of procrastination were also observed in online learning (Goda et al., 2015), as procrastinators were reported to achieve worse learning outcomes than non-procrastinators in the blended learning classes on the Moodle learning platform (Cerezo et al., 2017). The detrimental effects of procrastination during web-based programmes may be even more severe in comparison to the traditional classes because of increased intensity of task delays, which is typical of this form of education. As several authors indicated, the online learning environments seem to foster the tendency to procrastinate due to the increased autonomy of the participants, who have to organise their learning activities individually (Artino \& Stephens, 2009; You, 2015). Moreover, Romano et al. (2005) found that students enrolled in the blended learning courses procrastinated even more than more independent learners, who preferred less structured online courses with greater transitional distance. These results are in line with the notion that self-regulatory processes are critical in distance learning (Cho \& Schen, 2013). Thus, as previous findings demonstrated, the successful participation in the online programmes involving self-regulatory learning mainly depends on the motivational factors, metacognition, critical thinking, self-control, and time-management skills (Broadbent, \& Poon, 2015; Michinov et al., 2011, Yamada et al., 2015). For example, Rakes and Dunn (2010) showed that intrinsic motivation and effort regulation among online graduate students resulted in decreased tendency to procrastinate in the academic context, which, in turn, might lead to poorer outcomes during the online course.

Given the importance of the self-regulatory processes in online learning (Michinov et al., 2011), the key role in the blended learning environment seems to be played by another motivational variable - general self-efficacy. According to Bandura (1994), perceived self-efficacy refers to people's beliefs that they are able to influence important life events and constitutes a major factor in the selfregulation. Consequently, in line with the self-efficacy theory, the character of individuals' self-beliefs affects the motivational processes, especially by influencing the personal goals and standards, determination to succeed, perseverance, and 
ability to cope with difficulties. Academic procrastination - on the motivational level described as a self-regulatory failure (Steel, 2007) and widely analysed from a self-regulated learning perspective (Wolters, 2003) - is treated as a result of a poor self-regulation and motivational deficits, accompanying students' less favourable judgements about own capabilities, mostly noticeable in the academic sphere (Klassen et al., 2008). A large body of research indicates that general selfefficacy along with the domain-specific, academic self-efficacy are negatively related to procrastination in academic settings during traditional, face-to-face classes (e.g., Ferrari, Parker, \& Ware, 1992; Haycock, McCarthy, \& Skay, 1998; Klassen et al., 2008). The negative relation between both constructs was confirmed in previous metanalyses on procrastination (Steel, 2007; van Eerde, 2003). More recently, Wäschle et al. (2014) found that the interplay between self-efficacy and procrastination is dynamic in nature, and people with low self-efficacy who did not possess the record of previous goal achievement were prone to repeatedly engage in task delays. However, the effects of perceived self-efficacy on procrastination in blended learning have been much less studied. To date, most studies have concentrated on the role of self-efficacy in self-regulation learning with the exclusive usage of online platforms (Broadbent \& Poon, 2015). For instance, Cho and Shen (2013) showed that academic self-efficacy played an important role in academic achievement during e-learning courses. Thus, although the motivational factors affecting self-regulation processes during blended learning courses are widely analysed in the pedagogical and psychological literature, only several pieces of quantitative research have focused on students' self-beliefs, including their academic self-concept (e.g., Broadbent, 2017; Van Laer \& Elen, 2019; Yamada et al., 2016).

Additionally, the observable differences in the behavioural tendency to procrastinate in blended learning may stem from the individual differences in general propensity to procrastinate. A useful conceptual framework for investigating academic procrastination in the web-based programmes my provide the distinction between active and passive procrastination proposed by Chu and Choi (2005). According to this concept, active procrastination represents a potentially adaptive side of a deliberate task delay, connected with proper time management, effective self-regulation, high self-efficacy, and positive consequences. Passive procrastination, in turn, embodies a dysfunctional type of procrastination, characterised in terms of self-regulatory deficits, difficulties in coping with time pressure, negative self-efficacy beliefs, and poor personal outcomes (Choi \& Moran, 2009; Chu \& Choi, 2005). Because procrastination in online learning context in large part derives from deficits in self-regulatory processes (Dunn, 2014; Rakes \& Dunn, 2010), it was expected that learning patterns during blended learning courses would be positively associated with a more general concept of passive procrastination, in which procrastination is treated as a self-regulatory failure (Steel, 2007). The existing empirical data indicate that traditional, passive procrastination may 
manifest in the form of putting off important learning activities in blended learning courses, which involve self-regulated learning, and are largely based on motivation to work remotely (Broadbent, 2017; Cho \& Shen, 2013; Michinov et al., 2011). In contrast, active procrastination may be unrelated to the behavioural tendency to procrastinate in online learning, resulting from motivational deficits.

\section{Research Methodology}

\section{Aims and Hypotheses}

The current study was a preliminary attempt to identify the individual differences predictors of the behavioural tendency to procrastinate in the blended learning environment among university students from Poland. Given previous findings on the nature of education with the use of e-learning platforms, two categories of potential determinants of procrastination in blended learning were proposed. Firstly, general self-efficacy was tested as a predictor of procrastination in blended learning. Additionally, two kinds of procrastination differentiated by Choi and Moran (2005) within the individual differences framework - active and passive procrastination (c.f. Klingsieck, 2013a) - were analysed in relation to behavioural indicators of procrastination during the face-to-face university courses involving the usage of the Moodle e-learning platform. Thus, the main aim of the present study was to investigate the associations between general self-efficacy, active and passive procrastination, and procrastination in blended learning.

Since self-regulatory deficits may manifest in the form of ineffective time management during the e-learning university course (e.g., Broadbent $\&$ Poon, 2015; Cho \& Shen, 2013; Yamada et al., 2016), it was hypothesised that general self-efficacy would be negatively related to procrastination in the blended learning environment. In addition, to better understand which factors determine the individual behavioural tendency to engage in putting off learning activities during the blended learning courses, the associations between active and passive procrastination, and self-reported procrastination in blended learning were examined. Because postponing different activities during the online courses in higher education is regarded as an ineffective learning behavioural strategy (Goda et al., 2015), procrastination in e-learning and blended learning was identified with a socially undesirable form of task delay in the academic context. Given the dysfunctional nature of passive procrastination, the significant positive link was expected between passive procrastination and the behavioural tendency to procrastinate in blended learning. Active procrastination was not expected to be significantly correlated with procrastination during the blended learning courses based on the usage of the Moodle platform and face-to-face classes, since this 
form of procrastination embodies more adaptive, deliberate task delays leading to positive outcomes rather than impulsive acts of dysfunctional procrastination resulting from poor self-regulation (Corkin, Yu, \& Lindt, 2011).

\section{Participants and Procedure}

The present study relies on a convenience sample, comprising 108 undergraduate students ( 90 female, 18 male) from the University of Silesia in Katowice, participating in human resource management programme. The age of participants ranged from 17 to 47 years $(M=21.33, S D=.38)$. Of this group, $40.7 \%$ were in the first year of studies, while the remaining $41.7 \%$ and $17.6 \%$ were in their second and third years of studies, respectively. The number of Moodle courses into which respondents were enrolled during their studies varied between 1 and 11 $(M=5.21, S D=2.51)$. Throughout the study, 82 participants $(75.9 \%)$ were taking part in at least one blended learning course via Moodle platform at the university, combining traditional, face-to-face, and online classes. The present study was anonymous and voluntary. All students provided informed consent and obtained no financial compensation for participating in the study. During the management classes they received general written information about the nature of the study, provided sociodemographic data, and completed four self-report measures grouped in the standardised order.

\section{Measures}

The scales applied in the present study assess university students' general selfefficacy, active and passive procrastination along with the behavioural tendency to procrastinate in blended learning. The scales used to measure different types of procrastination were back-translated.

General self-efficacy. General self-efficacy was measured with the General Self-Efficacy Scale (GSES; Schwarzer \& Jerusalem, 1995) in Polish adaptation by Schwarzer, Jerusalem, and Juczyński (2001). The 10-item scale makes it possible to assess the perceived overall ability to effectively cope with different life stressors and challenges by the individual (Luszczynska, Scholz, \& Schwarzer, 2005). Participants responded to each statement (e.g., "I can always manage to solve difficult problems if I try hard enough") on the 4-point scale, ranging from 1 ("no") to 4 ("yes"). Higher scores in the GSES indicate higher levels of general selfefficacy. In the present study the internal consistency of the scale was satisfactory $(\alpha=.84)$.

Active procrastination. Active procrastination was assessed using the Active Procrastination Scale (APS) developed by Choi and Moran (2009) as a measure of intentional delay in completing the task activities. The APS consists of 16 statements (e.g., "In order to make better use of my time, I intentionally put off some tasks") rated on a 7-point scale (1 - "not at all true"; 7 - "very true") with 
higher scores reflective of greater active procrastination. In this study the APS demonstrated good reliability $(\alpha=.83)$.

Passive procrastination. The passive, dysfunctional type of procrastination in the academic context was measured using the Tuckman Procrastination Scale (TPS; Tuckman, 1991). This instrument comprises 16 items with a 7-point, Likerttype response scale ( 1 - "That's not me for sure"; 4 - "That's me for sure"). The scale includes such exemplary statements as "I am an incurable time waster" or "I needlessly delay finishing jobs, even when they're important". Higher scores in the TPS indicate grater passive procrastination. The reliability of the scale was $\operatorname{good}(\alpha=.85)$.

Procrastination in blended learning. To assess the university students' behavioural tendency to procrastinate in a blended learning environment, the 5-item scale by Artino and Stephens (2009) was used. The measure is a modified version of the scales earlier applied by Wolters $(2003 ; 2004)$ in the research concerning academic procrastination during traditional, face-to-face courses. Respondents were asked to rate each statement on the 7-point response scale, ranging from 1 ("Completely disagree") to 7 ("Completely agree"). Sample items are: "I often find excuses for not starting the work for this course" and "I frequently put off getting started on the readings and assignments for this course." Reliability for this scale in the present study was satisfactory $(\alpha=.89)$.

\section{Data Analysis}

In the present study SPSS version 25.0 was used to perform all statistical analyses. In the first step, means, standard deviations, and intercorrelations among the study variables were calculated. Secondly, to test the hypotheses concerning the relations between general self-efficacy, active and passive procrastination, and procrastination in the blended learning environment, the multiple hierarchical regression analysis was conducted.

\section{Research Results}

Table 1 contains descriptive statistics and zero-order correlations among the study variables. As hypothesised, passive procrastination was positively correlated with the tendency to engage in task delays during the blended learning course $(r=.61, p<.001)$. On the other hand, active procrastination was not significantly correlated with behavioural procrastination during the university programme using Moodle learning platform $(r=-.08, p>.05)$. Contrary to the expectations, general self-efficacy was unrelated to procrastination in blended learning $(r=-.15$, $p>.05)$. Additionally, two sociodemographic characteristics of the undergraduates 
(i.e., year of study and past experience in blended learning) were negatively linked to behavioural procrastination in blended learning. Students from higher years $(r=-.26, p<.01)$ and those who previously participated in larger numbers of online learning courses $(r=-.24, p<.01)$ reported lower levels of behavioural procrastination in blended learning. Other sample characteristics, including age, gender, and present participation in a blended learning course, revealed no significant associations with procrastination in blended learning.

Table 1.

Descriptive statistics and zero-order correlations among study variables

\begin{tabular}{|c|c|c|c|c|c|c|c|c|c|}
\hline Variable & 1. & 2. & 3. & 4. & 5. & 6. & 7. & 8. & 9. \\
\hline 1. Age & - & & & & & & & & \\
\hline $\begin{array}{l}\text { 2. Gender } \\
(\text { male }=0, \text { female }=1)\end{array}$ & -.13 & - & & & & & & & \\
\hline 3. Year of study & $.28^{* *}$ & .20 & - & & & & & & \\
\hline $\begin{array}{l}\text { 4. Present } \\
\text { participation in } \\
\text { a blended learning } \\
\text { course } \\
(\text { no }=0, \text { yes }=1)\end{array}$ & $-.37^{* * *}$ & $-.19^{*}$ & $-.69^{* * *}$ & - & & & & & \\
\hline $\begin{array}{l}\text { 5. Number of previous } \\
\text { online learning } \\
\text { courses }\end{array}$ & .13 & .08 & $.71^{* * *}$ & $-.29^{* *}$ & - & & & & \\
\hline 6. Self-efficacy & .16 & $-.22^{*}$ & .01 & -.04 & .10 & - & & & \\
\hline $\begin{array}{l}\text { 7. Active } \\
\text { procrastination }\end{array}$ & .05 & -.13 & .17 & -.04 & .16 & $.40^{\star \star *}$ & - & & \\
\hline $\begin{array}{l}\text { 8. Passive } \\
\text { procrastination }\end{array}$ & -.17 & -.01 & -.12 & .01 & $-.20^{*}$ & -.17 & $-.26^{*}$ & - & \\
\hline $\begin{array}{l}\text { 9. Procrastination in } \\
\text { blended learning }\end{array}$ & -.12 & .02 & $-.26^{* *}$ & .15 & $-.24^{*}$ & -.15 & -.08 & $.61^{* * *}$ & - \\
\hline$M$ & 21.33 & .83 & 1.77 & .76 & 5.17 & 30.72 & 63.23 & 41.12 & 21.04 \\
\hline$S D$ & 3.39 & .37 & .73 & .43 & 2.51 & 4.55 & 14.34 & 8.18 & 7.36 \\
\hline
\end{tabular}

Note $: N=108, * p<.05, * * p<.01,{ }^{* * *} p<.001$.

To determine if general self-efficacy along with active and passive procrastination significantly predicted the behavioural tendency to procrastinate in blended learning, hierarchical multiple regression analysis was conducted. The results of this analysis are presented in Table 2. In the first step, two control variables were entered into the model, such as year of study and past experience in web-based educational programmes measured by the number of previous online learning courses in which the students had participated. Those variables were significantly linked to procrastination in the previous correlation analysis. Although the first 
model, including control variables, was statistically significant $(F(2,105)=4.18$, $p<.05, R^{2}=.07$ ), year of study and past experience connected with blended learning in higher education were insignificant in predicting procrastination in blended learning. In the second step of the regression analysis, the three hypothesised variables (i.e., self-efficacy, active and passive procrastination), were entered simultaneously into the model. The final model remained statistically significant $\left(F(5,102)=15.05, p<.001, R^{2}=.40\right)$. In this model, year of study was a significant negative predictor $(\beta=-.24, p<.05)$, whereas passive procrastination was a significant positive predictor $(\beta=.60, p<.001)$.

Table 2.

Hierarchical regression analysis predicting behavioural procrastination in blended learning

\begin{tabular}{lccc}
\hline \multirow{2}{*}{ Predictors } & \multicolumn{3}{c}{ Procrastination in blended learning } \\
\cline { 2 - 4 } & $B(S E)$ & $\beta$ & $\Delta R^{2}$ \\
\hline Step 1 & & & $.07^{*}$ \\
Year of study & $-1.84(1.35)$ & -.18 & \\
Number of previous online learning courses & $-.32(.39)$ & -.11 & \\
Step 2 & & & $.35^{* * *}$ \\
Year of study & $-2.41(1.09)$ & $-.24^{*}$ & \\
Number of previous online learning courses & $.12(.32)$ & .04 & \\
Self-efficacy & $-.18(.13)$ & -.11 & \\
Active procrastination & $.08(.04)$ & .15 & \\
Passive procrastination & $.54(.07)$ & $.60^{* * *}$ & \\
\hline
\end{tabular}

Note : $N=108, * p<.05, * * p<.01, * * * p<.001$.

\section{Discussion}

The phenomenon of academic procrastination both in traditional and webbased courses is widely studied from the individual differences perspective (Steel \& Klingsieck, 2016). Additionally, as the online learning environment is described in terms of high autonomy, many studies concerning e-learning or/and blended learning include analyses of self-regulatory strategies accompanying the process of learning (Broadbent, 2017). The current study adopts this approach by examining relationships between general self-efficacy, active and passive procrastination, and the behavioural tendency to procrastinate in the blended learning course delivered via the Moodle online learning platform. 
As hypothesised, passive procrastination positively predicted postponing learning activities in the blended learning programme via the Moodle online platform. This result suggests that those students who procrastinate online exhibit more dysfunctional learning habits, which derive from more general individual differences in passive procrastination (cf. Choi \& Moran, 2009; Chu \& Choi, 2005; Romano et al., 2005). In line with this view, passive procrastination defined as a dispositional variable (van Eerde, 2003) - manifests in the academic context, among others, in putting off learning activities in the blended learning environment. Moreover, the strong positive linkage between passive procrastination and the behavioural tendency to postpone important tasks during the blended learning course suggest that both constructs are conceptually similar, or even redundant, and may reflect individual deficits in self-regulation (Steel, 2007). However, the problem of potential conceptual overlap of both variables needs further studies.

In contrast to passive procrastination, active procrastination did not serve as a significant predictor of procrastination in blended learning. From the motivational perspective, this finding seems to reflect behavioural differences among passive and active procrastinators, stemming from characteristic for each group's selfregulatory processes (Choi \& Moran, 2009; Chu \& Choi, 2005). In accordance with the existing empirical evidence, the adaptive qualities of active procrastination in the educational context were not noted with regard to behavioural procrastination (Hensley, 2014). Consequently, due to the grater self-control, individuals high in active procrastination may use relatively more effective time management strategies and exhibit less detrimental behavioural patterns during the blended learning courses in comparison to passive procrastinators. Nevertheless, the tendency to engage in active procrastination in the web-based courses still may lead to worse personal outcomes than forming a regulated learning habit in the online learning environment (Goda et al., 2015, Corkin et al., 2011).

Contrary to the expectations, general self-efficacy was not associated with procrastination in blended learning. Such a result is inconsistent with the existing literature on self-regulated learning in academic settings (Dunn, 2014; Cho \& Shen, 2013) and may derive from using a short, 5 -item scale to assess procrastination in blended learning, which could not capture all important aspects of this phenomenon, especially connected with the characteristics of self-regulated learning. Alternatively, the insignificant correlation between both variables may indicate that different factors (e.g., personality, contextual, cognitive) play a key role in this form of academic procrastination (Steel \& Klingsieck, 2016). For instance, the construct of academic self-efficacy might be better for estimating individual self-beliefs in the academic domain than the concept of general self-efficacy. Prior results proved that academic self-efficacy played important role in predicting academic achievement in e-learning (Cho \& Shen, 2013), and academic procrastination largely depended on self-variables different than general self-efficacy (Klassen et al., 
2008). Thus, further studies on procrastination in blended learning analysed from the self-regulatory perspective should also involve these motivational variables.

An additional negative correlation was found between the number of previous e-learning courses in which the respondent participated and behavioural procrastination in blended learning. These findings suggest that other dispositional factors affect the preference for self-regulated learning during studies. For example, as previous empirical evidence indicates, conscientiousness may affect the individual willingness to engage in procrastination (Steel, 2007). Thus, as Romano et al. (2005) noted, self-selection may be an important factor influencing preference for e-learning programmes, and, in turn, more independent and diligent students tend to choose distant learning university courses that not require strict supervision. However, future research should test the role of conscientiousness and other personality traits as predictors of procrastination in the blended learning environment. Furthermore, the negative linkage between year of study and procrastination in blended learning suggests that students over time acquire better learning habits and new learning skills useful in the blended learning environment.

Although the present study emphasised the important and largely understudied in Polish culture problem of procrastination in blended learning, it had several significant limitations. First of all, this investigation was correlational in nature and relied exclusively on the self-reported data, including a single, 5-item, comprehensive scale used to measure procrastination in blended learning. Meanwhile, prior findings indicate that further experimental studies on procrastination in blended learning based on observable data are needed, especially as the basis of determining implications of learning styles for online instructors and students (Artino \& Stephens, 2009). The further limitation is connected with the relatively small size and convenience character of the research sample. Taking into account the preliminary nature of the present study, it is worth to replicate it on a larger, more diverse community sample, comprising students form different faculties. Despite the worldwide popularity of Moodle as an open source online management learning system in higher education, future research on procrastination in blended learning should also involve other web-based course platforms (Brandl, 2005). Adopting a broader perspective in studies concerning distance learning is all the more important as past findings indicate that various learning solutions differ significantly in terms of usability (Martin et al., 2008) and adaptivity (Reyes et al., 2009). An additional problem with this study was that it included only general self-efficacy along with active and passive procrastination as possible predictors of the behavioural tendency to procrastinate in blended learning. However, as the psychological antecedents of academic procrastination may be examined from different perspectives (Steel \& Klingsieck, 2016), the approach involving solely individual differences variables, which was adopted in this study, should be extended in the next studies. Especially, as previous research shows, interesting findings could emerge by testing potential personality, cognitive, affective, and 
situational predictors of procrastination during the web-based programmes dedicated to universities (Fernie et al., 2017; Steel \& Klingsieck, 2016; You \& Kang, 2014). For example, Krause, Stark, and Mandl (2009) found that such contextual variable as the teacher's feedback interventions had beneficial effects on the student's objective learning outcomes by reducing knowledge deficits. Accordingly, taking such a broad approach in studies on determinants of blended learning might lead to establishing new methods of intervention in online education aimed at minimalising academic procrastination.

The present study has several important theoretical and practical implications in the context of online learning. Firstly, it contributes to the existing literature on academic procrastination in asynchronous, online classes by examining the associations between individual differences variables and the behavioural tendency to procrastinate during online learning courses in higher education. As mentioned earlier, in line with past findings (Steel, \& Klingsieck, 2016), the obtained results highlight the importance of analysing academic procrastination from different theoretical perspectives, not only from the perspective concentrating on the selfregulatory mechanisms in learning and teaching processes. However, given the preliminary and cross-sectional character of the current study, further research in the field of educational psychology is needed. Moreover, the obtained results may be useful in planning online teaching strategies (cf. Cho \& Shen, 2013). The strong positive linkage between passive procrastination and its behavioural manifestations in the online learning environment demonstrates that the strategies for intervention and prevention of procrastination in higher education should focus on the more general tendency to delay scholastic tasks. This notion is consistent with the recommendation by Kachgal, Hansen, and Nutter (2001), who postulate increasing students' self-awareness of own tendency to procrastinate as a primary intervention in the online learning environment.

\section{Conclusions}

To summarise, this study aimed to investigate relationships between general self-efficacy, active and passive procrastination, and the behavioural tendency to procrastinate in blended learning. As hypothesised, passive procrastination was positively linked to procrastination in blended learning, indicating that both constructs might share the same conceptual core, connected with self-regulatory deficits. In contrast, active procrastination revealed statistically insignificant correlation with behavioural procrastination in blended learning. These results highlight the conceptual differences between active and passive task delays. Moreover, contrary to expectations, perceived self-efficacy displayed nonsignificant 
relationship with procrastination in blended learning. Such findings suggest that future research on procrastination in blended learning should involve other dispositional and situational factors, which might better predict the tendency to putt off learning activities in web-based programmes. The additional analysis of relationships between the sociodemographic characteristics of the sample and the hypothesised variables revealed that students' previous experience in the blended learning environment (measured by the number of successfully completed blended learning courses in the past) was negatively associated with procrastination in blended learning. This relation might be explained in light of the hypothesis of self-selection in distance learning courses (Romano et al., 2005). Probably more conscientious and independent individuals are prone to choose classes involving online learning activities that require and promote such dispositions. However, future research, based on a larger and more diverse sample from the general population, is needed in order to test this assumption.

\section{References}

Artino, A. R. \& Stephens, J. M. (2009). Academic motivation and self-regulation: A comparative analysis of undergraduate and graduate students learning online. The Internet and Higher Education, 12(3-4), 146-151.

Bandura, A. (1994). Self-efficacy. In V. S. Ramachaudran (Ed.), Encyclopedia of human behavior (Vol. 4, pp. 71-81). New York: Academic Press. (Reprinted in H. Friedman [Ed.], Encyclopedia of mental health. San Diego: Academic Press, 1998).

Brandl, K. (2005). Review of Are You Ready to "Moodle"? Language Learning \& Technology, $9(2), 16-23$.

Broadbent, J. (2017). Comparing online and blended learner's self-regulated learning strategies and academic performance. Internet and Higher Education, 33, 24-32.

Broadbent, J. \& Poon, W. L. (2015). Self-regulated learning strategies \& academic achievement in online higher education learning environments: A systematic review. The Internet and Higher Education, 27, 1-13.

Cerezo, R., Esteban, M., Sánchez-Santillán, M., \& Núñez, J. C. (2017). Procrastinating behavior in computer-based learning environments to predict performance: A case study in Moodle. Frontiers in Psychology, 8, 1403. https://doi.org/10.3389/fpsyg.2017.01403.

Cho, M. H. \& Shen, D. (2013). Self-regulation in online learning. Distance Education, 34(3), 290-301.

Choi, J. N. \& Moran, S. V. (2009). Why not procrastinate? Development and validation of a new active procrastination scale. The Journal of Social Psychology, 149(2), 195-212.

Chu, A. H. C. \& Choi, J. N. (2005). Rethinking procrastination: Positive effects of" active" procrastination behavior on attitudes and performance. The Journal of Social Psychology, 145(3), $245-264$.

Corkin, D. M., Yu, S. L., \& Lindt, S. F. (2011). Comparing active delay and procrastination from a self-regulated learning perspective. Learning and Individual Differences, 21(5), 602-606. 
Dunn, K. (2014). Why wait? The influence of academic self-regulation, intrinsic motivation, and statistics anxiety on procrastination in online statistics. Innovative Higher Education, 39(1), 33-44.

Fernie, B. A., Bharucha, Z., Nikčević, A. V., Marino, C., \& Spada, M. M. (2017). A Metacognitive model of procrastination. Journal of Affective Disorders, 210, 196-203.

Ferrari, J. R., O'Callaghan, J., \& Newbegin, I. (2005). Prevalence of procrastination in the United States, United Kingdom, and Australia: arousal and avoidance delays among adults. North American Journal of Psychology, 7(1), 1-6.

Ferrari, J. R., Parker, J. T., \& Ware, C. B. (1992). Academic procrastination: Personality correlates with Myers-Briggs types, self-efficacy, and academic locus of control. Journal of Social Behavior and Personality, 7, 495-502.

Gafni, R. \& Geri, N. (2010). Time management: Procrastination tendency in individual and collaborative tasks. Interdisciplinary Journal of Information, Knowledge, and Management, 5(1), $15-125$.

Garrison, D. R. \& Kanuka, H. (2004). Blended learning: Uncovering its transformative potential in higher education. The Internet and Higher Education, 7(2), 95-105.

Goda, Y., Yamada, M., Kato, H., Matsuda, T., Saito, Y., \& Miyagawa, H. (2015). Procrastination and other learning behavioral types in e-learning and their relationship with learning outcomes. Learning and Individual Differences, 37, 72-80.

Graham, C. R. (2006). Blended learning systems: Definition, current trends, and future directions. In C. J. Bonk \& C. R. Graham (Eds.), The handbook of blended learning (pp. 3-21). San Francisco, CA: Preiffer.

Haycock, L. A., McCarthy, P., \& Skay, C. L. (1998). Procrastination in college students: The role of self-efficacy and anxiety. Journal of Counseling \& Development, 76(3), 317-324.

Hensley, L. C. (2014). Reconsidering active procrastination: Relations to motivation and achievement in college anatomy. Learning and Individual Differences, 36, 157-164.

Jaworska-Gruszczyńska, I. (2016). Prokrastynacja - struktura konstruktu a stosowane skale pomiarowe [Procrastination - the structure of the construct and the measuring scales]. Testy Psychologiczne w Praktyce i Badaniach, 2(1), 36-59.

Kachgal, M. M., Hansen, L. S., \& Nutter, K. J. (2001). Academic procrastination prevention/intervention: Strategies and recommendations. Journal of Developmental Education, 25(1), 14-24.

Kim, K. R. \& Seo, E. H. (2015). The relationship between procrastination and academic performance: A meta-analysis. Personality and Individual Differences, 82, 26-33.

Klassen, R. M., Krawchuk, L. L., \& Rajani, S. (2008). Academic procrastination of undergraduates: Low self-efficacy to self-regulate predicts higher levels of procrastination. Contemporary Educational Psychology, 33(4), 915-931.

Klingsieck, K. B. (2013a). Procrastination: When good things don't come to those who wait. European Psychologist, 18, 24-34.

Klingsieck, K. B. (2013b). Procrastination in different life-domains: Is procrastination domain specific?. Current Psychology, 32(2), 175-185.

Krause, U. M., Stark, R., \& Mandl, H. (2009). The effects of cooperative learning and feedback on e-learning in statistics. Learning and Instruction, 19(2), 158-170.

Luszczynska, A., Scholz, U., \& Schwarzer, R. (2005). The general self-efficacy scale: multicultural validation studies. The Journal of Psychology, 139(5), 439-457.

Lynch, R., \& Dembo, M. (2004). The relationship between self-regulation and online learning in a blended learning context. The International Review of Research in Open and Distributed Learning, 5(2), 1-16. https://doi.org/10.19173/irrodl.v5i2.189.

Markiewicz, K. \& Dziewulska, P. (2018). Procrastination predictors and moderating effect of personality traits, Polskie Forum Psychologiczne, 23(3), 593-609. 
Martin, L., Martínez, D. R., Revilla, O., Aguilar, M. J., Santos, O. C., \& Boticario, J. G. (2008, February). Usability in e-Learning Platforms: heuristics comparison between Moodle, Sakai and dotLRN. In Sixth International Conference on Community based environments. Guatemala (pp. 12-16).

Means, B., Toyama, Y., Murphy, R., \& Baki, M. (2013). The effectiveness of online and blended learning: A meta-analysis of the empirical literature. Teachers College Record, 115(3), 1-47.

Michinov, N., Brunot, S., Le Bohec, O., Juhel, J., \& Delaval, M. (2011). Procrastination, participation, and performance in online learning environments. Computers \& Education, 56(1), 243-252.

Rakes, G. C. \& Dunn, K. E. (2010). The Impact of Online Graduate Students' Motivation and SelfRegulation on Academic Procrastination. Journal of Interactive Online Learning, 9(1), 78-93.

Reyes, N. R., Candeas, P. V., Galan, S. G., Viciana, R., Canadas, F., \& Reche, P. J. (2009, June). Comparing open-source e-learning platforms from adaptivity point of view. In 2009 EAEEIE Annual Conference (pp. 1-6). IEEE.

Romano, J., Wallace, T. L., Helmick, I. J., Carey, L. M., \& Adkins, L. (2005). Study procrastination, achievement, and academic motivation in web-based and blended distance learning. The Internet and Higher Education, 8(4), 299-305.

Schwarzer, R. \& Jerusalem, M. (1995). Generalized self-efficacy scale. Measures in health psychology: A user's portfolio. Causal and control beliefs, 1(1), 35-37.

Schwarzer, R., Jerusalem, M., \& Juczyński, Z. (2001). Skala Uogólnionej Własnej Skuteczności GSES [Generalized Self-Efficacy Scale - GSES]. In Z. Juczyński (Ed.), Narzędzia pomiaru w promocji zdrowia i psychologii zdrowia (pp. 93-97). Warszawa: Pracownia Testów Psychologicznych PTP.

Shea, P. \& Bidjerano, T. (2010). Learning presence: Towards a theory of self-efficacy, self-regulation, and the development of a communities of inquiry in online and blended learning environments. Computers \& Education, 55(4), 1721-1731.

Sirois, F. \& Pychyl, T. (2013). Procrastination and the priority of short-term mood regulation: Consequences for future self. Social and Personality Psychology Compass, 7(2), 115-127.

Steel, P. (2007). The nature of procrastination: A meta-analytic and theoretical review of quintessential self-regulatory failure. Psychological Bulletin, 133(1), 65-94.

Steel, P. \& Klingsieck, K. B. (2016). Academic procrastination: Psychological antecedents revisited. Australian Psychologist, 51(1), 36-46.

Stępień, M. \& Topolewska, E. (2014). Style tożsamości w ujęciu Berzonsky’ego a prokrastynacja [Identity Styles in Bierzonsky's Approach and Procrastination]. In E. Topolewska, E. Skimina, S. Skrzek (Eds.), Młoda psychologia (Vol. 2, pp. 145-160). Warszawa: Wydawnictwo Stowarzyszenia Filomatów.

Tuckman, B. W. (1991). The development and concurrent validity of the procrastination scale. Educational and Psychological Measurement, 51(2), 473-480.

Van Eerde, W. (2003). A meta-analytically derived nomological network of procrastination. Personality and Individual Differences, 35(6), 1401-1418.

Van Laer, S. \& Elen, J. (2019). The effect of cues for calibration on learners' self-regulated learning through changes in learners' learning behaviour and outcomes. Computers \& Education, 135, $30-48$.

Wäschle, K., Allgaier, A., Lachner, A., Fink, S., \& Nückles, M. (2014). Procrastination and selfefficacy: Tracing vicious and virtuous circles in self-regulated learning. Learning and Instruction, $29,103-114$.

Wolters, C. A. (2003). Understanding procrastination from a self-regulated learning perspective. Journal of Educational Psychology, 95(1), 179-187. 
Wolters, C. A. (2004). Advancing achievement goal theory: Using goal structures and goal orientations to predict students' motivation, cognition, and achievement. Journal of Educational Psychology, 96, 236-250.

Yamada, M., Goda, Y., Matsuda, T., Kato, H., \& Miyagawa, H. (2015). The Relationship Among SelfRegulated Learning, Procrastination, And Learning Behaviors In Blended Learning Environment. 12th International Conference on Cognition and Exploratory Learning in Digital Age 2015, 67-74. Greater Dublin, Ireland. http://eric.ed.gov/?id=ED562147.

Yamada, M., Goda, Y., Matsuda, T., Saito, Y., Kato, H., \& Miyagawa, H. (2016). How does selfregulated learning relate to active procrastination and other learning behaviors? Journal of Computing in Higher Education, 28(3), 326-343.

You, J. W. (2015). Examining the Effect of Academic Procrastination on Achievement Using LMS Data in E-learning. Educational Technology \& Society, 18(3), 64-74.

You, J. W., \& Kang, M. (2014). The role of academic emotions in the relationship between perceived academic control and self-regulated learning in online learning. Computers \& Education, 77, $125-133$.

Elżbieta Sanecka

\title{
Prokrastynacja w blended learningu: rola poczucia własnej skuteczności oraz aktywnej i pasywnej prokrastynacji
}

\author{
Streszczenie
}

Pomimo wzrastającego zainteresowania empirycznego prokrastynacją akademicką w kontekście kształcenia na odległość, istnieje niewiele badań poświęconych temu zjawisku w odniesieniu do programów blended learning. W przeprowadzonym badaniu analizowano zależności między uogólnionym poczuciem własnej skuteczności, dwoma rodzajami prokrastynacji (aktywną i pasywną prokrastynacją) oraz behawioralną tendencją do odkładania w czasie aktywności związanych z nauką w trakcie uniwersyteckiego kursu z wykorzystaniem platformy Moodle. Uzyskane wyniki pokazały, że pasywna prokrastynacja wykazuje silny negatywny związek z prokrastynacją w blended learningu, podczas gdy spostrzegane poczucie własnej skuteczności oraz aktywna prokrastynacja są niepowiązane z deklarowanym odkładaniem w czasie zadań podczas kursu blended learning. Dodatkowo wykazano istnienie negatywnego związku między zgłaszaną liczbą ukończonych wcześniej kursów blended learning a prokrastynacją w blended learningu. Praktyczne i teoretyczne implikacje otrzymanych wyników w odniesieniu do nauczania z wykorzystaniem metody blended learning zostały omówione w podsumowaniu.

Słow a kluc zowe: prokrastynacja, blended learning, poczucie własnej skuteczności, aktywna prokrastynacja, pasywna prokrastynacja 


\title{
Elżbieta Sanecka
}

\section{Прокрастинация в комбинированном обучении: роль чувства собственной продуктивности и активной или пассивной прокрастинации}

\author{
Анно о а ция
}

Несмотря на растущий эмпирический интерес к академической прокрастинации в контексте дистанционного образования, существует недостаточное количество исследований, посвященных этому феномену в обучении с использованием комбинированных образовательных программ. В ходе проведенного исследования была проанализирована зависимость между обобщенным чувством собственной продуктивности, двумя видами прокрастинации (т. е., активной и пассивной) и поведенческой тенденцией к откладыванию действий, связанных с приобретением знаний по системе дистанционного обучения через платформу Moodle. Полученные результаты показали, что пассивная прокрастинация демонстрирует сильную отрицательную связь с прокрастинацией в смешанном обучении, в то время как воспринимаемое чувство собственной продуктивности и активная прокрастинация не связаны с откладыванием «на потом» выполнения заданий при смешанном образовании, когда темп и интенсивность обучения определяются самим учащимся. Кроме того, подтверждено существование отрицательной связи между зарегистрированным числом образовательных курсов, завершенных в более короткий период времени и прокрастинацией, связанной с комбинированным обучением. Практические и теоретические импликации полученных результатов, касающихся обучения по методу комбинированного образования, рассмотрены в выводах.

Кл юч е в ы е с л о в а: прокрастинация, комбинированное (смешанное) обучение, самоэффективность, активная прокрастинация, пассивная прокрастинация

Elżbieta Sanecka

\section{Procrastinación en el blended learning: el papel de la autoeficacia y la procrastinación activa y pasiva}

\author{
Resumen
}

A pesar del creciente interés empírico en la procrastinación académica en el contexto del aprendizaje a distancia, hay pocos estudios dedicados a este fenómeno en relación con los programas del blended learning (aprendizaje combinado). El estudio realizado analizó la relación entre la autoeficacia generalizada, dos tipos de procrastinación (es decir, la procrastinación activa y pasiva) y una tendencia conductual a posponer las actividades relacionadas con el aprendizaje durante el curso académico utilizando la plataforma Moodle. Los resultados obtenidos mostraron que la procrastinación pasiva muestra una fuerte relación negativa con la procrastinación en el blended learning, mientras que la autoeficacia y la procrastinación activa no están relacionadas con el aplazamiento declarado de tareas durante el curso del blended learning. Además, se mostró una relación negativa entre la cantidad de cursos del blended learning completados previamente y la procrastinación en el blanded learning. Las implicaciones prácticas y teóricas de los resultados obtenidos en relación con la enseñanza utilizando el método del blended learning se describen en las conclusiones.

Palabras clave: procrastinación, blended learning, autoeficacia, procrastinación activa, procrastinación pasiva 